DOI: http://dx.doi.org/10.18203/2320-1770.ijrcog20182325

Original Research Article

\title{
Cesarean scar pregnancy: an upcoming challenge
}

\author{
Sunil K. Juneja, Pooja Tandon*, Bhanupriya
}

Department of Obstetrics and Gynecology, Dayanand Medical College and Hospital, Ludhiana, Punjab, India

Received: 08 March 2018

Revised: 24 April 2018

Accepted: 30 April 2018

\section{*Correspondence:}

Dr. Pooja Tandon,

E-mail: drpoojatandon77@gmail.com

Copyright: () the author(s), publisher and licensee Medip Academy. This is an open-access article distributed under the terms of the Creative Commons Attribution Non-Commercial License, which permits unrestricted non-commercial use, distribution, and reproduction in any medium, provided the original work is properly cited.

\section{ABSTRACT}

Background: Cesarean scar pregnancy (CSP) is a type of ectopic pregnancy implanted in the myometrium at the site of previous cesarean scar. Incidence of cesarean deliveries are increasing globally, leading to rise in incidence of cesarean scar pregnancy. Caesarean scar pregnancies are associated with some life-threatening complications such as scar rupture, haemorrhage, disseminated intravascular coagulation, requiring lifesaving hysterectomy. We present our experience with 11 patients with cesarean scar pregnancy, diagnosed using transvaginal colour doppler ultrasound during 3-year period and treated conservatively to preserve the uterus with successful outcome in all patients.

Methods: This was a retrospective study, conducted in the Department of Obstetrics and Gynecology of DMC\&H, Ludhiana from January 2015 to December 2017. Out of total deliveries (4278), 3.9\% (171/4278) were diagnosed as ectopic pregnancy. $6.43 \%$ (11/171) of them were diagnosed as cesarean scar ectopic pregnancy. After counseling, all patients underwent conservative management. Injection methotrexate $50 \mathrm{mg}$ was administered intramuscularly and beta- HCG was monitored after 4 days and then weekly till it was $<1$.

Results: 2 patients had an increase in beta HCG levels on day 7 and required second dose of methotraxate. 8 patients required blood transfusion due to excessive bleeding on admission. In 9 patients beta HCG levels reduced to $<1$ in 7 weeks post first methotraxate dose administration, and in remaining 3 it returned to $<1$ after 8 weeks . No patient required any surgical intervention.

Conclusions: Cesarean scar pregnancy, a type of ectopic pregnancy can be safely managed conservatively if diagnosed early.

Keywords: Cesarean scar, Challenge, Pregnancy

\section{INTRODUCTION}

Ectopic pregnancy (EP) is defined as the implantation of a fertilized ovum outside the endometrial cavity. It accounts for approximately $1.3-2 \%$ of all pregnancies. ${ }^{1}$ Cesarean scar pregnancy (CSP) is a type of ectopic pregnancy implanted in the myometrium at the site of previous cesarean scar. ${ }^{2}$ Incidence is cesarean deliveries are increasing globally, leading to rise in rates of cesarean scar pregnancy. Throughout the world 6.2 Million unnecessary CDs are being performed annually., ${ }^{2,3}$ An average annual increase of $4.4 \%$ is seen in incidence of cesarean scar pregnancy. ${ }^{4}$ The measurement of serum beta-human chorionic gonadotropin ( $\beta$-hCG) and the use of ultrasound imaging have helped in early and more accurate diagnosis of CSP, thereby facilitating the successful preservation of the uterus without causing maternal complications. ${ }^{5}$

Caesarean scar pregnancies are associated with some lifethreatening complications such as scar rupture, haemorrhage, disseminated intravascular coagulation, requiring lifesaving hysterectomy. ${ }^{6}$

Several types of conservative treatments have been used like- dilatation and curettage, excision of trophoblastic 
tissue (laparotomy or laparoscopy), local and or systemic administration of methotrexate, bilateral hypogastric artery ligation or selective uterine artery embolization combined with curettage and/or methotrexate administration. ${ }^{7}$ We present our experience with 11 patients with cesarean scar pregnancy, diagnosed using transvaginal colour doppler ultrasound during 3-year period and treated conservatively to preserve the uterus with successful outcome in all the patients.

\section{METHODS}

This was a retrospective study, conducted in the Department of Obstetrics and Gynecology of DMC and H, Ludhiana from January 2015 to December 2017, total deliveries at our institute were 4278. Out of them $3.9 \%$ (171/4278) were diagnosed as ectopic pregnancy. Cesarean scar ectopic pregnancy was diagnosed in $6.43 \%$ $(11 / 171)$ of them.

All our patients had received some form of treatment from outside (MTP Pill or surgical MTP) and had presented to us with complaint of excessive bleeding per vaginum. All these cases were undiagnosed or misdiagnosed from outside. MTP pill had been taken by 9 out of 11. Dilatation and evacuation (D\&E) after pill intake was done in 3 out of these 9.2 out of 11 patients had undergone D\&E before coming to our institute (Table 1).

Diagnosis was confirmed if all of the following sonographic criteria were met: 1) an empty uterine cavity, with a clearly demonstrated endometrium; 2) an empty cervical canal; and 3) a gestational sac, with or without fetal cardiac activity, was located in the anterior part of the uterine isthmus, embedded in and surrounded by the myometrium and the fibrous tissue of the scar, and separated from the endometrial cavity or fallopian tube. ${ }^{8}$

Serum beta HCG levels were sent after diagnosis using transvaginal Doppler ultrasound. After counseling, all patients underwent conservative management. First dose of methotrexate $(50 \mathrm{mg})$ was administered after getting haemogram, renal function tests (RFT) and liver function tests (LFT). Follow up done using Beta HCG levels on day 4, day7 and then weekly till it was $<1$, and superseded by ultrasonography at weekly intervals for 4 weeks then monthly for 3 months.

\section{RESULTS}

Gestational age at diagnosis ranged from 5 weeks +4 days to 8 weeks +2 days (Table 1 ). Early presentation and diagnosis is important to assign medical treatment.

Table 1: Clinical profile of patients.

\begin{tabular}{|c|c|c|}
\hline Gestation at diagnosis & Modality for diagnosis & Treatment done outside \\
\hline 7weeks 4 days & USG with doppler & MTP Pill+ evacuation \\
\hline 7 weeks 0 days & USG with doppler & MTP Pill+ evacuation \\
\hline 8 weeks 1 days & USG with doppler & Surgical MTP \\
\hline 5weeks 4 days & USG with doppler & MTP Pill \\
\hline 6weeks 0days & USG with doppler & MTP Pill \\
\hline 6 weeks 5 days & USG with doppler & Surgical MTP \\
\hline 7 weeks 3 days & USG with doppler & MTP Pill+ evacuation \\
\hline 7 weeks 1 days & USG with doppler & MTP Pill \\
\hline 8 weeks 2 days & USG with doppler & MTP Pill \\
\hline 7 weeks 4 days & USG with doppler & MTP Pill \\
\hline 6 weeks 5 days & USG with doppler & MTP Pill \\
\hline
\end{tabular}

Table 2: Transfusion requirement.

\begin{tabular}{|ll|}
\hline No. of blood transfusions required & Interval between treatment outside to admission in DMCH (days) \\
\hline 1 & 4 \\
\hline 1 & 11 \\
\hline 2 & 21 \\
\hline 2 & 12 \\
\hline 0 & 8 \\
\hline 1 & 4 \\
\hline 1 & 6 \\
\hline 2 & 7 \\
\hline 0 & 7 \\
\hline 0 & 4 \\
\hline
\end{tabular}


Table 3: Temporal fall in B- HCG.

\begin{tabular}{|llllllllll|}
\hline Day 0 & Day 4 & Day 7 & Day 14 & Day 21 & Day 28 & Day 35 & Day 42 & Day 49 & Day 56 \\
\hline 1076 & 514 & 130 & 54 & 10 & 06 & 2 & 1 & $<1$ & $<1$ \\
\hline 1384 & 633 & 215 & 76 & 13 & 05 & 1.5 & 1.2 & $<1$ & $<1$ \\
\hline 1209 & 544 & 330 & 63 & 09 & 03 & 1.4 & 1 & $<1$ & $<1$ \\
\hline 987 & 322 & 112 & 43 & 17 & 04 & 1 & 1.1 & $<1$ & $<1$ \\
\hline 1108 & 284 & 146 & 23 & 12 & 05 & 1 & 1 & $<1$ & $<1$ \\
\hline 1084 & 714 & 816 & 134 & 54 & 24 & 7 & 4.2 & 2.5 & $<1$ \\
\hline 1273 & 480 & 233 & 34 & 17 & 10 & 2 & 1.2 & $<1$ & $<1$ \\
\hline 886 & 372 & 228 & 23 & 08 & 03 & 1.2 & 1.2 & $<1$ & $<1$ \\
\hline 1410 & 218 & 786 & 164 & 60 & 27 & 11 & 3.6 & 1.2 & $<1$ \\
\hline 1205 & 404 & 117 & 11 & 04 & 02 & 1 & $<1$ & $<1$ & $<1$ \\
\hline 1138 & 334 & 106 & 23 & 07 & 03 & 1.5 & $<1$ & $<1$ & $<1$ \\
\hline
\end{tabular}

All patients presented to our institute at an average of 8 days after previous treatment. 8 patients required blood transfusion due to excessive bleeding on admission (Table 2).

On follow up, 2 patients had an increase in beta HCG levels on day 7 and required second dose of methotrexate. In 9 patients beta HCG levels reduced to $<1$ in 7 weeks post first methotrexate dose administration, and in remaining 3 it returned to $<1$ after 8 weeks (Table 3 ). No patient required any surgical intervention.

\section{DISCUSSION}

The first case of CSP was reported in 1978 by Larsen and Solomon. ${ }^{9}$ Increased use of ultrasound in early gestation and the rising rate of cesarean section delivery have led to rapidly rising incidence of CSP. ${ }^{10}$ Incidence in our study is found to be 1: 400 ectopic pregnancies which is very high as compared to incidence in other studies, where it ranges from 1 per 2226 to 1 per 1800 pregnancies. ${ }^{11,12}$ The reason for this high incidence is because our hospital is a tertiary care and referral centre, where complicated cases are being referred from all nearby cities.

Ultraonography is a reliable first-line diagnostic tool. Color flow Doppler measurement can provide additional information for diagnosis. High-velocity, prominent, lowimpedance blood flow can be detected surrounding an ectopic gestational sac, consistent with normal early pregnancy. ${ }^{13}$

Magnetic resonance imaging has been used as an adjunct to ultrasound scan. Assessment of the pelvic structures is better with MRI because of the improved differentiation of soft tissue, better spatial resolution, and the possibility of multiplanar imaging. However, a major limitation of MRI is its long acquisition time. Many authors do not routinely recommend MRI for diagnosing cesarean scar pregnancy, and transvaginal ultrasound is still the best diagnostic imaging tool that should be applied in the first step. ${ }^{14}$

Till today, there is still no universal treatment guideline available. With the rising incidence of CSP, accumulating data suggested a variety of medical and surgical treatment modalities. ${ }^{15}$ Treatment should be individualized on the basis of the desire for future fertility, gestational age of the pregnancy and hemodynamic stability.

The most common type of medical therapy that is suitable for use in early pregnancy is methotraxate. It may be administered systemically or locally and single or multidose regime may be used. Systemic administration of methotrexate is a standard treatment for tubal ectopic pregnancy, so there should be no reason to doubt its efficacy on cesarean scar pregnancy. But, systemic methotrexate appears to be more effective in women with B-HCG level $<5000 \mathrm{mU} / \mathrm{mL}$ according to the literature. ${ }^{13,16}$ In our study all the patients had B- HCG levels $<5000 \mathrm{mU} / \mathrm{mI}$. In only 2 patients multidose $(2$ doses) were required. Success rate was $100 \%$ in our study. No patient required any surgical intervention.

\section{CONCLUSION}

Cesarean scar pregnancy is a type of ectopic pregnancy. A strong sense of suspicion is required to diagnose this type of pregnancy i.e when cervical canal and uterine cavity are empty and fetus is located in the vicinity of cesarean scar. Early diagnosis can prevent scar rupture and various other complications, thereby decreasing morbidity and mortality. Treatment is individualized but conservative management should be the first line management wherever possible.

\section{Funding: No funding sources}

Conflict of interest: None declared

Ethical approval: The study was approved by the Institutional Ethics Committee 


\section{REFERENCES}

1. Barnhart KT. Clinical practice. Ectopic pregnancy. N Engl J Med. 2009;361:379-87.

2. Betran AP, Torloni MR, Zhang JJ, et al. WHO Statement on caesarean section rates. BJOG. 2016;123(5):667-70.

3. Gibbons L, Belizan JM, Lauer JA, Betrán AP, Merialdi M, Althabe F. The global numbers and costs of additionally needed and unnecessary caesarean sections performed per year: overuse as a barrier to universal coverage. World Health Rep. 2010;30:1-31.

4. Winder SR, Condous G. Ultrasound Diagnosis of Ectopic Pregnancy. AJUM. 2011;14 (2):29-33.

5. Clark EA, Silver RM. Long-term maternal morbidity associated with repeat cesarean delivery. Am J Obstet Gynecol. 2011;205:S2-10.

6. Collins K, Kothari A. Catastrophic consequences of a caesarean scar pregnancy missed on ultrasound. Australasian Journal of Ultrasound in Medicine. 2015;18(4):150-6.

7. Seow KM, Cheng WC, Chuang J, Lee C, Tsai YL, Hwang JL. Methotrexate for cesarean scar pregnancy after in vitro fertilization and embryo transfer. A case report. J Reprod Med. 2000;45:754-7.

8. Alammari R, Thibodeau R, Harmanli O. Vaginal hysterectomy for treatment of cervical ectopic pregnancy. Obstet Gynecol. 2017;129:63-5.

9. Ash A, Smith A, Maxwell D. Caesarean scar pregnancy. BJOG. 2007;114:253-63.

10. Larsen JV, Solomon MH. Pregnancy in a uterine scar sacculus: an unusual cause of postabortal haemorrhage. A case report. S Afr Med J. 1978;53:142-3.

11. Timor-Tritsch IE, Monteagudo A, Cali G. PalaciosJaraquemada JM, Maymon R, Arslan AA, et al. Cesarean scar pregnancy and early placenta accreta share common histology. Ultrasound Obstet Gynecol. 2014;43:383-95.

12. Osborn DA, Williams TR, Craig BM. Cesarean scar pregnancy: sonographic and magnetic resonance imaging fndings, complications, and treatment. J Ultrasound Med. 2012;31(9):1449-56.

13. Rotas MA, Haberman S, Levgur M. Cesarean scar ectopic pregnancies: etiology, diagnosis, and management. Obstet Gynecol. 2006;107:1373-81.

14. Jurkovic D, Jauniaux E, Kurjak A, Hustin J, Campbell S, Nicolaides KH. Transvaginal color Doppler assessment of the uteroplacental circulation in early pregnancy. Obstet Gynecol. 1991;77:365-9.

15. Maymon R, Halperin R, Mendlovic S, Schneider D, Herman A. Ectopic pregnancies in a caesarean scar: review of the medical approach to an iatrogenic complication. Hum Reprod Update. 2004;10:515523.

16. Birch Petersen K, Hoffmann E, Rifbjerg Larsen C, Svarre Nielsen $H$. Cesarean scar pregnancy: a systematic review of treatment studies. Fertil Steril. 2016;105(4):958-67.

Cite this article as: Juneja SK, Tandon P, Bhanupriya. Cesarean scar pregnancy: an upcoming challenge. Int J Reprod Contracept Obstet Gynecol 2018;7:2226-9. 